Rita Rahmaniati,Lilik Kholisotin \& Vicky Pratiwi Rachmawati. 2019. Upaya Meningkatkan Hasil Belajar Bahasa Arab dengan Menggunakan Media Pembelajaran Wayang Kreasi Pada Peserta Didik Kelas III A MIN 2 Kota Palangka Raya Tahun Pelajaran 2018/2019

Jurnal Hadratul Madaniyah, Volume 6 Issue I, Juli 2019, Page I - 9 P-ISSN: 2407-3865; e-ISSN: 2655-I993

\title{
UPAYA MENINGKATKAN HASIL BELAJAR BAHASA ARAB DENGAN MENGGUNAKAN MEDIA PEMBELAJARAN WAYANG KREASI PADA PESERTA DIDIK KELAS III A MIN 2 KOTA PALANGKA RAYA TAHUN PELAJARAN 2018/2019
}

\author{
${ }^{1}$ Rita Rahmaniati, ${ }^{2}$ Lilik Kholisotin, \& ${ }^{3}$ Vicky Pratiwi Rachmawati. \\ ${ }^{1}$ Lecturer in Elementary Teacher Education, Universitas Muhammadiyah Palangkaraya, RTA \\ Milono St. Km. 1,5, Palangka Raya, Indonesia. \\ ${ }^{2}$ Lecturer in Islamic Education, Universitas Muhammadiyah Palangkaraya, RTA Milono St. Km. \\ 1,5, Palangka Raya, Indonesia. \\ ${ }^{3}$ Students in Islamic Education, Universitas Muhammadiyah Palangkaraya, RTA Milono St. Km. \\ 1,5, Palangka Raya, Indonesia \\ *e-mail: rahmaniatirita@gmail.com
}

\begin{abstract}
ABSTRAK
Penelitian ini bertujuan untuk : (1) Untuk mengetahui peningkatan aktivitas belajar peserta didik kelas III A MIN 2 Kota Palangka Raya pada saat pembelajaran bahasa Arab dengan menggunakan media pembelajaran Wayang Kreasi. (2) Untuk mengetahui peningkatan hasil belajar peserta didik kelas III A MIN 2 Kota Palangka Raya pada saat pembelajaran bahasa Arab dengan menggunakan media pembelajaran Wayang Kreasi. Subjek dalam penelitian ini adalah peserta didik kelas III A MIN 2 Kota Palangka Raya yang berjumlah sebanyak 38 orang peserta didik, terdiri dari 22 laki-laki dan 16 perempuan. Metode dalam penelitian ini menggunakan metode Penelitian Tindakan Kelas (PTK) dengan menggunakan media pembelajaran Wayang Kreasi. Hasil penelitian menunjukkan bahwa : (1) Aktivitas belajar peserta didik kelas III A MIN 2 Kota Palangka Raya pada saat pembelajaran bahasa Arab dengan menggunakan media pembelajaran Wayang Kreasi menjadi baik. Berdasarkan hasil pengamatan yang diperoleh pada siklus I aktivitas peserta didik dengan ratarata 2,69 masih dalam kategori cukup baik dan pada siklus II aktivitas peserta didik dengan rata-rata 3,55 sudah termasuk dalam kategori baik. (2) Ada peningkatan hasil belajar peserta didik kelas III A MIN 2 Kota Palangka Raya setelah pembelajaran bahasa Arab dengan menggunakan media pembelajaran Wayang Kreasi. Pada siklus I hasil belajar peserta didik memperoleh nilai ratarata sebesar 64 dengan ketuntasan klasikal 58\% dan pada siklus II hasil belajar peserta didik memperoleh rata-rata sebesar 75 dengan ketuntasan klasikal 89,5\%.
\end{abstract}

Kata kunci : Hasil belajar bahasa Arab, Media Wayang Kreasi 
Rita Rahmaniati,Lilik Kholisotin \& Vicky Pratiwi Rachmawati. 2019. Upaya Meningkatkan Hasil Belajar Bahasa Arab dengan Menggunakan Media Pembelajaran Wayang Kreasi Pada Peserta Didik Kelas III A MIN 2 Kota Palangka Raya Tahun Pelajaran 2018/2019

Jurnal Hadratul Madaniyah, Volume 6 Issue I, Juli 2019, Page I - 9 P-ISSN: 2407-3865; e-ISSN: 2655-I993

\begin{abstract}
This study aims to: (1) To find out the increase of learning activities of class III A MIN 2 City of Palangka Raya at the learning of Arabic Language by using the media of learning Puppet Creations. (2) To know the improvement of learning outcomes of class III A MIN 2 City of Palangka Raya at the learning of Arabic Language by using the media of learning Puppet Creations. Subject in this study were students class III A MIN 2 City of Palangka Raya which amounted to 38 students, consisting of 22 men and 16 women. Methods in this research using Classroom Action Research method (PTK) by using the media of learning Puppet Creations. The results showed that: (1) The learning activity of students of class III A MIN 2 City of Palangka Raya at the learning of Arabic Language using the media of learning Puppet Creations to be good. Based on the observations obtained in the first cycle of student activity with an average of 2.69 is still in good enough category and on the second cycle of student activity with an average of 3.55 already included in either category. (2) There is an increase of learning outcomes of students of class III A MIN 2 City of Palangka Raya after learning Arabic Language by using Puppet Creations media. In the first cycle of learning outcomes learners get an average score of 64 with $58 \%$ classical completeness and on the second cycle of learning outcomes learners gain an average of 75 with $89.5 \%$ classical completeness.
\end{abstract}

Keywords: Arabic Learning Result, Puppet Creations Media, 


\section{PENDAHULUAN}

Bahasa memiliki peran penting dalam perkembangan intelektual, sosial, dan emosional bagi siapa saja khususnya peserta didik serta merupakan penunjang keberhasilan dalam mempelajari semua bidang studi. Bahasa diharapkan membantu peserta didik mengenal dirinya, budayanya dan budaya orang lain, mengemukakan gagasan dan perasaan, berpartisipasi dalam masyarakat yang menggunakan bahasa tersebut. Artinya bahwa bahasa sangat erat kaitannya dengan kegiatan berpikir, sehingga sistem bahasa yang berbeda akan melahirkan pola pikir yang berbeda pula. Guna mendukung tercapainya tujuan tersebut, diperlukan upaya berupa pendidikan dan pembelajaran bahasa yang memadai.

Upaya yang bisa dilakukan dalam pembelajaran bahasa sangat beragam, salah satunya adalah dengan menerapkan metode pembelajaran. Menurut William Francis Mackey, terdapat 15 buah tipe metode yang umum digunakan dalam pembelajaran bahasa. Metode tersebut diantaranya, yaitu a) Direct Method, b) Natural Method, c) Psycological Method, d) Phonetic Method, e) Reading Method, f) Grammar Method, g) Translation Method, h) Grammar Translation Method, i) Eclectic Method, j) Unit Method, k) Language-Control Method, 1) MimicryMemorization Method, m) PracticeTheory Method, n) Cognate Method, dan o) Dual-Language Method. (Henry Guntur Tarigan, 2009)

Mengingat pentingnya kedudukan bahasa dalam kegiatan pembelajaran, maka bahasa menjadi salah satu potensi yang perlu dikembangkan sejak usia dini. Bahasa menjadi salah satu bagian dari teori kecerdasan majemuk yang merupakan kemampuan untuk berpikir dalam bentuk kata-kata dan menggunakan bahasa untuk mengekspresikan dan menghargai makna yang kompleks ketika anak berkomunikasi dengan orang lain, sehingga bahasa dapat dikatakan sebagai jembatan penghubung seseorang kepada orang lain baik dalam berkomunikasi, berinteraksi dan mengutarakan apa yang ingin disampaikan, dalam hal ini komunikasi yang dilakukan antara peserta didik sebagai penerima pesan pembelajaran dan guru selaku pemberi informasi. Sebagaimana yang telah Allah SWT. sebutkan dalam Al-Qur'an surah Al-Baqarah ayat 31, tentang bahasa sebagai alat komunikasi manusia. Ayat tersebut berbunyi:

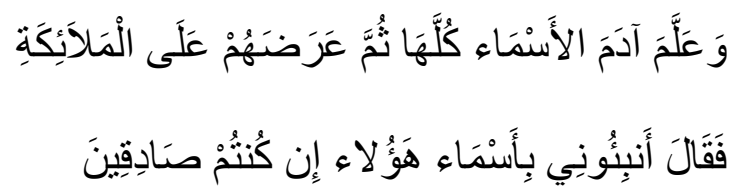

Artinya:

"Dan Dia ajarkan kepada Adam namanama (benda) semuanya, kemudian Dia perlihatkan kepada para malaikat seraya berfirman, "Sebutkan kepada-Ku nama semua (benda) ini, jika kamu yang benar!"

Menurut Kridalaksana, bahasa adalah sistem lambang arbitrer yang digunakan suatu masyarakat untuk bekerja sama, berinteraksi, dan mengidentifikasi diri. Terdapat beberapa istilah yang berkenaan dengan bahasa diantaranya, yaitu bahasa aglutinatif, bahasa akusatif, bahasa alamiah, bahasa nalitis, bahasa antara, bahasa asing, bahasa baku, bahasa bermajas, bahasa buatan, bahasa campuran, bahasa daerah, bahasa dialek, bahasa ibu, bahasa isyarat, bahasa kasar, bahasa kedua, bahasa kiasan, bahasa lisan, bahasa manusia, bahasa nasional, bahasa prokem, bahasa siul, bahasa tulisan, dan bahasa umum. (Amir F. Hidayat dan E. N. Rahmani, 2009) 
Berdasarkan observasi awal yang dilakukan peneliti, penguasaan kosakata bahasa Arab (mufradat) peserta didik belum memenuhi standar Kriteria Ketuntasan Minimal (KKM) yang telah diberlakukan di MIN 2 kota Palangka Raya yaitu 60. Dalam proses pembelajaran bahasa Arab di MIN 2 kota Palangka Raya pendidik menggunakan metode pembelajaran yang konvensional yakni ceramah, tanya jawab, dan pemberian tugas. Ternyata dengan menggunakan metode pembelajaran konvensional ini nilai hasil belajar mata pelajaran bahasa Arab peserta didik kelas III A MIN 2 kota Palangka Raya masih rendah. Adapun nilai hasil belajar mata pelajaran bahasa Arab pada materi namanama penyakit (اسماء الامراض pada semester I tahun pelajaran 2018/2019 dari 38 peserta didik hanya 12 orang yang mampu mencapai nilai KKM atau 32\% yang tuntas dan sebanyak 26 orang yang mendapat nilai dibawah KKM atau $68 \%$ yang tidak tuntas, ini menunjukkan bahwa hasil belajar bahasa Arab peserta didik kelas III A MIN 2 kota Palangka Raya masih rendah.

Menurut pantauan peneliti saat melakukan observasi, ada beberapa faktor yang menyebabkan kurangnya penguasaan kosakata bahasa Arab (mufradat) peserta didik yakni: faktor pertama, bahasa Arab merupakan bahasa kedua yang hanya dipelajari peserta didik ketika berada di sekolah; faktor kedua, penggunaan metode yang kurang variasi; faktor ketiga, penggunaan media yang kurang variatif, sehingga pembelajaran sering disampaikan secara lisan saja tanpa ada media pendukung yang dapat menarik minat peserta didik saat guru menjelaskan materi; dan faktor keempat, pendidik cenderung sebagai pusat pembelajaran (Teacher Centered) dan peserta didik hanya mendengarkan materi. Metode ceramah dan tanya jawab serta penggunaan buku paket sebagai LK
(Lembar Kerja) masih sering digunakan ketika menyampaikan materi sehingga peserta didik cepat merasa jenuh.

Seyogyanya pembelajaran bahasa Arab dapat menjadi pembelajaran yang menarik dan menyenangkan bagi peserta didik. Agar tujuan pembelajaran dapat dicapai, seorang pendidik dapat membuat beragam inovasi dalam proses belajar mengajar, salah satunya menggunakan media pembelajaran. Media pembelajaran merupakan segala sesuatu yang dapat menyalurkan pesan, dapat merangsang pikiran, perasaan, dan kemauan peserta didik sehingga dapat mendorong terciptanya proses belajar pada diri peserta didik. Secara umum manfaat media pembelajaran adalah memperlancar interaksi antara pendidik dengan peserta didik sehingga kegiatan pembelajaran lebih efektif dan efisien.

Selain itu dengan media pembelajaran pendidik dapat menampilkan informasi melalui suara, gambar, gerakan dan warna, baik secara alami maupun manipulasi, sehingga membantu pendidik untuk menciptakan suasana belajar menjadi lebih hidup, tidak monoton dan tidak membosankan. Salah satu media pembelajaran yang dapat digunakan guru untuk meningkatkan penguasaan kosakata bahasa Arab peserta didik adalah dengan menggunakan media Wayang Kreasi yang diaplikasikan dalam bentuk/kegiatan permainan. Tujuan peneliti memilih permainan yang menggunakan media Wayang Kreasi adalah agar pesan atau informasi yang dikomunikasikan lebih bersifat konkret sehingga mudah diserap dan diingat oleh peserta didik, disamping itu media ini mudah, murah, dan efisien dalam pembuatan dan penggunaanya.

Menurut Heinick, "Media pembelajaran adalah media-media yang membawa pesan-pesan atau informasi yang bertujuan untuk pembelajaran atau mengandung maksud-maksud (Rodhatul Jennah, 2009) Menurut 
Criticos, menyatakan bahwa media adalah salah satu komponen komunikasi, yaitu sebagai pembawa pesan dari komunikator menuju komunikan. Yang mana berdasarkan pernyataan tersebut, dapat dikatakan bahwa proses pembelajaran merupakan proses komunikasi. (Daryanto, 2016) Berdasarkan pendapat para ahli di atas maka dapat disimpulkan bahwa media pembelajaran adalah salah satu alat perantara atau pengantar informasi yang didapat dari sumber dan dikirimkan kepada penerima informasi yaitu peserta didik, guna mendorong terjadinya proses belajar untuk mencapai tujuan pembelajaran.

Menurut Ardian Kresna, wayang adalah wujud dari upaya penggambaran nenek moyang suku Jawa tentang kehidupan manusia pada umumnya. Selanjutnya menurut Nizz Arrahman, mendefinisikan istilah wayang kontemporer dapat diartikan sebagai wayang yang tidak terikat oleh aturan-aturan zaman dulu (pakem) dan berkembang sesuai perkembangan zaman. (Ardian Kresna, 2012) Wayang kontemporer mulai ada dan dikenal masyarakat sejak tahun 1920, lewat wayang ciptaan R.M Sutarto Harjowahono yang diberi nama Wayang Wahana. Wayang kontemporer adalah perwujudan baru dari seni wayang saat akulturasi budaya dan eksplorasi seni rupa mulai diangkat dan diadopsi guna memperkaya khasanah rupa dan bentuk wayang. (Vemaska Kirana, 2016) Dari penjelasan diatas dapat disimpulkan bahwa wayang kreasi adalah wayang yang sudah dimodifikasi sedemikian rupa dan ceritanya tidak pakem seperti halnya dengan wayang purwa.

Langkah-langkah media pembelajaran Wayang Kreasi yaitu 1) Pendidik menjelaskan tujuan pembelajaran 2) Pendidik menyiapkan wayang kreasi tentang الامراض 3) Pendidik menyampaikan materi pelajaran tentang nama-nama penyakit اسماء الامراض 4) Pendidik menunjukkan wayang kreasi bermacam-macam penyakit 5) Pendidik meminta peserta didik mengemukakan isi wayang kreasi tersebut 6) Pendidik membagi peserta didik menjadi berpasang-pasangan 7) Pendidik meminta beberapa pasangan maju ke depan kelas untuk menyebutkan bergantian اسماء beserta artinya 8) Pendidik mengajak peserta didik menghubungkan dengan pengalaman seharihari.

Kelebihan dan kelemahan media pembelajaran Wayang Kreasi (Daryanto, 2016) sebagai berikut 1) Efisien terhadap waktu, tempat, biaya, dan persiapan 2) Tidak memerlukan keterampilan yang rumit 3) Dapat mengembangkan imajinasi dan aktivitas anak dalam suasana gembira. Kelemahan media pembelajaran Wayang Kreasi 1) Perlu tempat penyimpanan yang aman 2) Mudah rusak jika terkena air dan api 3) Harus selalu dalam pengawasan orang dewasa.

\section{METODE PENELITIAN}

Jenis penelitian menggunakan Jenis Penelitian Tindakan Kelas (PTK) dengan dua rancangan siklus yang direncanakan. Menurut kardiawarman (Paizaluddin dan Ermalinda, 2014) Penelitian Tindakan Kelas berasal dari bahasa Inggris Classroom Action Research, yang berarti penelitian yang dilakukan pada sebuah kelas untuk mengetahui akibat tindakan yang diterapkan pada suatu subyek penelitian di kelas tersebut. Menurut Arikunto (Suyadi, 2012) PTK terdiri dari tiga kata, yaitu penelitian, tindakan dan kelas. Pertama, penelitian. Penelitian diartikan sebagai kegiatan mencermati suatu objek dengan menggunakan cara dan aturan atau metodologi tertentu untuk menemukan data akurat tentang hal-hal yang dapat meningkatkan mutu objek yang diamati. Kedua, tindakan. Tindakan 
merupakan gerakan yang dilakukan dengan sengaja dan terencana dengan tujuan tertentu. Ketiga, kelas. Kelas adalah tempat di mana terdapat sekelompok peserta didik yang dalam waktu bersamaan menerima pelajaran dari guru yang sama. Berdasarkan pendapat para ahli di atas, maka dapat disimpulkan bahwa penelitian tindakan kelas (PTK) adalah sebuah penelitian yang dilakukan oleh pendidik di kelasnya sendiri dengan jalan merencanakan, melaksanakan, dan merefleksikan tindakan secara kolaboratif dan partisipatif dengan tujuan untuk memperbaiki kinerjanya sebagai pendidik, sehingga hasil belajar peserta didik dapat meningkat.

Dalam penelitian ini, kehadiran dan peran peneliti sangat diperlukan dalam setiap kegiatan di tempat penelitian. Dengan menyadari adanya permasalahan dalam proses pembelajaran di kelas maka kehadiran peneliti mutlak diperlukan. Peneliti berperan sebagai perencana, pelaksana tindakan, pengamat, pengumpul dan sebagai pelapor hasil penelitian. Peneliti juga berkolaborasi dengan guru kelas dan teman sejawat yang berperan sebagai pengamat (observer) yang bertugas selama proses penelitian dengan menggunakan lembar pengamatan yang telah disediakan oleh peneliti.

Penelitian ini dilaksanakan di MIN 2 Kota Palangka Raya, dimana subjek penelitian ini adalah peserta didik kelas III A MIN 2 kota Palangka Raya tahun pelajaran 2018/2019 yang berjumlah 38 orang peserta didik. Teknik penelitian dalam penelitian ini melalui tes dan observasi. Observasi dalam penelitian ini adalah observasi langsung yaitu observasi dilakukan dengan cara pengamatan secara langsung untuk mengetahui hasil, tingkah laku, aktivitas peserta didik dan pendidik di dalam kelas, dan objek yang diteliti secara langsung saat pembelajaran di kelas. Adapun tes dalam penelitian ini ada dua macam, yaitu tes tertulis yang berupa pilihan ganda serta rubrik keterampilan menulis, dan tes lisan yang berupa rubrik keterampilan berbicara. Teknik tes ini terdiri dari dua macam yaitu pre test dan post test.

Data dalam penelitian ini dianalisis secara kualitatif dan kuantitatif. Data kualitatif diperoleh dari aktivitas pendidik dan peserta didik dalam pembelajaran yang dikelola pendidik dengan penerapan media pembelajaran Wayang Kreasi. Sedangkan data kuantitatif berasal dari pretest yang dilakukan diawal pertemuan dan posttest yang dilakukan diakhir pembelajaran dengan rumus:

$$
\overline{\mathrm{X}}=\frac{\sum X}{N}
$$

Keterangan:

$\overline{\mathrm{X}}=$ Nilai rata-rata kelas

$\sum \mathrm{X}=$ Total nilai yang diperoleh peserta didik

$\mathrm{N}=$ Jumlah peserta didik

$$
T B=\frac{\sum s \geq 60}{N} \times 100 \%
$$

Keterangan:

$\sum s \quad=$ Jumlah peserta didik yang mendapatkan nilai sama 60

$\mathrm{N}=$ Banyak peserta didik

$100 \%=$ Bilangan tetap presentase

$\mathrm{TB}=$ Ketuntasan belajar klasikal minimal $85 \%$

\section{HASIL DAN PEMBAHASAN}

\section{Aktivitas Peserta Didik}

Data aktivitas pendidik dan peserta didik saat pembelajaran dengan menggunakan media Wayang Kreasi.

\section{Gambar 1. Grafik Hasil Observasi Aktivitas Peserta Didik}




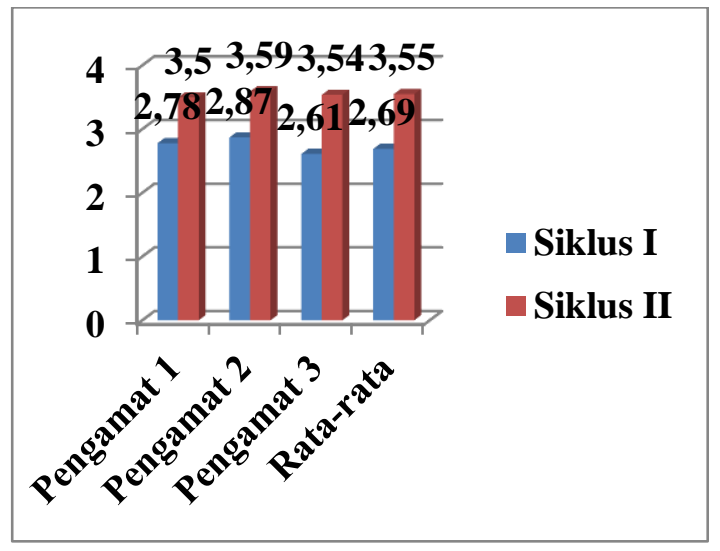

Berdasarkan gambar di atas dapat dilihat adanya peningkatan aktivitas peserta didik pada kegiatan belajar mengajar siklus I dan siklus II dengan menggunakan media pembelajaran Wayang Kreasi. Hasil pengamatan tiga observer pada siklus I dengan rata-rata 2,69 dan pada siklus II dengan rata-rata 3,55 .

\section{Hasil Belajar Bahasa Arab Peserta Didik}

Hasil belajar peserta didik dengan menggunakan media pembelajaran Wayang Kreasi mengalami peningkatan. Hal tersebut dapat dilihat dari hasil belajar peserta didik yang diperoleh dari data awal pra tindakan. Pada awal pra tindakan hasil belajar peserta didik memperoleh skor rata-rata 53,5 dengan ketuntasan klasikal 32\% yang masih sangat jauh dari kriteria ketuntasan klasikal minimal 85\%. Kemudian pada siklus I diperoleh hasil belajar peserta didik dengan skor rata-rata 64 dengan ketuntasan klasikal 58\% yang masih belum memenuhi kriteria ketuntasan klasikal minimal $85 \%$.

Sedangkan, pada siklus II diperoleh hasil belajar peserta didik dengan skor rata-rata 75 dengan ketuntasan klasikal 89,5\% yang sudah memenuhi kriteria ketuntasan klasikal minimal $85 \%$. Meningkatnya hasil belajar peserta didik dengan menggunakan media pembelajaran Wayang Kreasi dikarenakan pada saat mengajar pendidik menjelaskan materi menggunakan media Wayang Kreasi sehingga peserta didik dapat secara langsung memahami dan melihat apa yang sedang dijelaskan dan disampaikan oleh pendidik. Selain itu, pendidik juga meminta peserta didik untuk maju berpasangan melakukan tanya jawab sederhana mengenai materi, sehingga peserta didik lebih dapat memahami serta menggunakan media Wayang Kreasi secara langsung.

Hal tersebut didasari karena media Wayang Kreasi ini memberikan kesempatan untuk peserta didik melaksanakan tugas-tugas dalam situasi nyata dan memberikan kesempatan kepada peserta didik untuk mengalami situasi yang nyata serta melatih keterampilan peserta didik. Berikut ini adalah tabel hasil belajar peserta didik dari data awal pra tindakan, siklus I dan siklus II.

\section{Gambar 2. Grafik Hasil Belajar Peserta Didik}

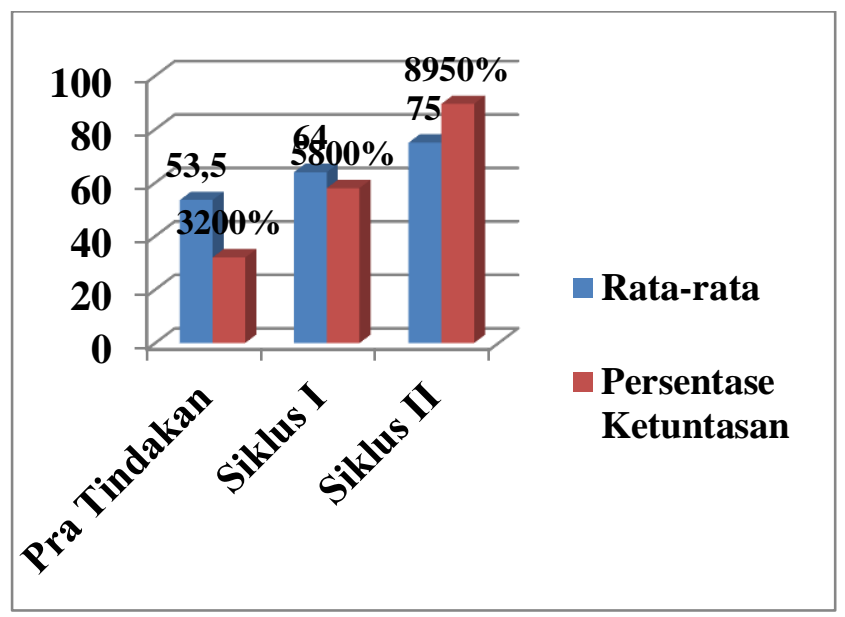

Berdasarkan gambar di atas terlihat adanya peningkatan hasil belajar peserta didik kelas III A MIN 2 Kota Palangka Raya yang berjumlah sebanyak 38 orang peserta didik dari sebelum menggunakan media pembelajaran Wayang Kreasi diperoleh persentase hasil belajar $32 \%$ dengan rata-rata 53,5. Sedangkan pada siklus I persentase hasil belajar $58 \%$ 
Rita Rahmaniati,Lilik Kholisotin \& Vicky Pratiwi Rachmawati. 2019. Upaya Meningkatkan Hasil Belajar Bahasa Arab dengan Menggunakan Media Pembelajaran Wayang Kreasi Pada Peserta Didik Kelas III A MIN 2 Kota Palangka Raya Tahun Pelajaran 2018/2019

Jurnal Hadratul Madaniyah, Volume 6 Issue I, Juli 2019, Page I - 9 p-ISSN: 2407-3865; e-ISSN: 2655-1993

dengan rata-rata 64 dan untuk penelitian selanjutnya pada siklus II persentase hasil belajar $89,5 \%$ dengan rata-rata 75 diukur berdasarkan ketuntasan klasikal. Serta, pada siklus II ada empat orang peserta didik yang nilainya belum mencapai KKM 60.

\section{KESIMPULAN}

Aktivitas belajar peserta didik kelas III A MIN 2 Kota Palangka Raya pada saat pembelajaran bahasa Arab dengan menggunakan media pembelajaran Wayang Kreasi menjadi baik. Ada peningkatan hasil belajar peserta didik kelas III A MIN 2 Kota Palangka Raya setelah pembelajaran bahasa Arab dengan menggunakan media pembelajaran Wayang Kreasi. 
Rita Rahmaniati,Lilik Kholisotin \& Vicky Pratiwi Rachmawati. 2019. Upaya Meningkatkan Hasil Belajar Bahasa Arab dengan Menggunakan Media Pembelajaran Wayang Kreasi Pada Peserta Didik Kelas III A MIN 2 Kota Palangka Raya Tahun Pelajaran 2018/2019

Jurnal Hadratul Madaniyah, Volume 6 Issue I, Juli 2019, Page I - $9 \quad$ p-ISSN: 2407-3865; e-ISSN: 2655-1993

\section{DAFTAR PUSTAKA}

Daryanto. 2016. Media Pembelajaran. Yogyakarta: Penerbit Gava Media.

F. Hidayat, Amir dan E. N. Rahmani. 2009. Bahasa-Bahasa Dunia \& Peristilahan dalam Bahasa. Jawa Barat: CV Pustaka Grafika.

Guntur Tarigan, Henry. 2009. Metodologi Pengajaran Bahasa 1. Bandung: ANGKASA.

Jennah, Rodhatul. 2009. Media Pembelajaran. Banjarmasin: Antasari Press.

Kirana, Vemaska. 2016. "Pembelajaran Kesenian Wayang Kreasi Untuk Mengetahui Minat Anak Terhadap Wayang", Jurnal UNNES, Vol. 1, No. 1, Oktober 2016.

Kresna, Ardian. 2012. Mengenal Wayang. Yogyakarta: Laksana.

Paizaluddin dan Ermalinda. 2014. Penelitian Tindakan Kelas (Classroom Action Research). Bandung: Alfabeta.

Suyadi. 2012. Buku Panduan Guru Profesional Penelitian Tindakan Kelas (PTK) dan Penelitian Tindakan Sekolah (PTS). Yogyakarta: ANDI. 